\title{
Cobalt and Copper Contents of Some Tropical Soils and Grasses from Puerto Rico
}

\author{
Julián Roldán Regús
}

\section{INTRODUCTION AND LITERATURE REVIEW}

Copper deficiency symptoms have been observed mostly in fruit trees where the young growing tips stop their growth and die. In Puerto Rico copper deficiency symptoms have been observed in some citrus fruits but no report has been published.

Cobalt deficiency in cattle in Puerto Rico has not been reported, but the literature is abundant in cases of cobalt deficiency in cattle from various other countries. As scientific literature regarding these elements in tropical soils and crops is nil, it was considered that data gathered about this subject would help in closing the gap in our knowledge.

Copper deficiency symptoms were observed in sugarcane growing in sawgrass peat soils (16)..$^{2} \mathrm{~A}$ tremendous response was observed when the soil was treated with copper salts. Harmer, (5) working with several crops on organic soils, showed that a considerable response to copper is obtained if the soil $\mathrm{pH}$ is around 6.0 or below.

A deficiency of copper in forage areas has caused diarrhea, loss of appetite, and anemia in cattle. In Australia, a chronic copper deficiency resulting from a low content in the herbage has been responsible for a cattle disease known as the "falling disease". This disease is characterized by staggering, falling, and instantaneous death (10).

\section{MATERIALS AND METHODS}

Soil and grass species samples were taken at random from square plots with an area of 16 square feet in each of the location and soil types shown in the tabulation that follows.

\section{Location}

Sucesión Ricardo La Costa Barrio Higuillar, Dorado

Finca Hnos. Piñero, Barrio Canovanillas West of Canovanillas River and North of Carolina, Canóvanas Road Finca Agustín López-Ramírez in Barrio Canóvanas, East of Canóvanas and South of Canóvanas Río Grande Road Finca Celestino Pérez Compañía Agrícola Bairoa Caguas Nicasio Betancourt Humacao

\section{Soil lype}

Coloso silt loam

Toa silt loam Coloso silty clay

Toa silt loam

Coloso silty clay

Caguas clay

Toa sandy loam

Cayaguá sandy loam

${ }^{2}$ Soil Chemist, Agricultural Experiment Station, Mayagüez Campus, University of Puerto Rico, Río Piedras, Puerto Rico.

Italic numbers in parentheses refer to Literature Cited, pp. 355-6. 
Table 1 shows the common and scientific names of the plant material analyzed and the soil types where the grasses were growing. The grass species consisted of malojilla, malojillo, merker grass, and a mixture of native grasses and legumes as indicated in the table.

The soil samples were mostly taken at a depth of 0-6 inches although some samples were taken at $0-12$ inches and some at $6-12$ inches. The grass samples were dried in an oven at $70^{\circ} \mathrm{C}$, ground in a Wiley mill, mixed and a representative subsample taken. This subsample was placed in an oven at $80^{\circ} \mathrm{C}$ for several days.

TABLE 1.-Plant material and soil types analyzed

\begin{tabular}{l|l|l}
\hline \multirow{2}{*}{ Soil type } & \multicolumn{2}{|c}{ Kinds of plants or species } \\
\cline { 2 - 3 } & \multicolumn{1}{|c}{ Common name } & \multicolumn{1}{|c}{ Scientific name } \\
\hline Coloso silt loam & Malojilla & Eriochloa polystachya \\
Toa silt loam & Pasto Amargo & Paspalum conjugatum \\
Coloso silty clay & Yerba Dulce & Eleusine indica \\
& Carpet Grass & Taxonopus compressus \\
Coqui & Cyperus (spp.) \\
Coloso silty clay & Escobilla & Vernonia sericea \\
& Zarzabacoa & Meibomia supina \\
& Morivivf & Mimosa pudica \\
& Cerrillo & Sporobolus indicus \\
& San Agustin & Stenotaphrum secundatum \\
Grama de Costa & Chloris radiata \\
Caguas clay & Arrocillo & Setaria geniculata \\
Cayagud sandy loam & Botoncillo Blanco & Borreria verticillata \\
Toa sandy loam & Merker Grass & Pennisetum purpureum \\
\hline & Malofillo & Panicum purpurascens \\
\hline
\end{tabular}

The $\mathrm{pH}$ of the soil samples was determined in a 1:2.5 soil-water ratio by means of a potentiometer. Soil samples in which total copper and cobalt were determined, were previously digested with perchloric acid according to the method of Holmes (7). Cobalt was determined by a modified procedure of the method of McNaught, and the methods of Kidson and Askew as quoted by Piper (14). Copper was determined by a modification of the procedures of Coulson (2), and Marston and Dewey (9), as quoted by Parks et al. (13).

The grass samples were analyzed for total copper following the method of Holmes (7). Cobalt was determined by a modified procedure of the method of McNaught, and the method of Kidson and Askew as quoted by Piper (14). 


\section{RESULTS AND DISCUSSION}

Tables 2 and 3 give the minimum, maximum, and average cobalt and copper content in the different soil types studied. Tables 4 and 5 give the minimum, maximum, and average cobalt and copper content of the grasses analyzed.

Of the soils studied, the Cayagua sandy loam had the lowest average cobalt content, and the highest average copper content. The Toa sandy

TABLE 2.-Coball content in different soil types

\begin{tabular}{l|c|c|c|c}
\hline \multirow{2}{*}{ Soil type } & \multicolumn{3}{|c}{ Cobalt content expressed in parts per million } \\
\cline { 2 - 5 } & Samples & Minimum & Maximum & Average \\
\hline & Number & p.p.m. & p.p.m. & p.p.m. \\
Coloso silt loam & 4 & 0.2 & 0.5 & 0.4 \\
Toa silt loam & 3 & .3 & 3.5 & 1.6 \\
Coloso silty clay & 4 & .1 & 1.5 & .7 \\
Caguas clay & 5 & .1 & 1.3 & .4 \\
Toa sandy loam & 4 & .9 & 5.6 & 2.8 \\
Cayauge sandy loam & 4 & .2 & .2 & .2 \\
\hline
\end{tabular}

TaBLE 3.-Copper content in different soil types

\begin{tabular}{l|c|c|c|c}
\hline \multirow{2}{*}{ Soil type } & \multicolumn{3}{|c|}{ Copper content expressed in parts per million } \\
\cline { 2 - 6 } & Samples & Minimum & Maximum & Average \\
\hline Number & $p . p . m$. & $p . p . m$. & $p . p . m$. \\
Coloso silty loam & 4 & 49 & 83 & 65.8 \\
Toa silt loam & 4 & 54 & 74 & 67.0 \\
Coloso silty clay & 4 & 35 & 93 & 63.8 \\
Caguas clay & 5 & 60 & 91 & 74.3 \\
Toa sandy loam & 4 & 38 & 51 & 44.5 \\
Cayaguá sandy loam & 5 & 52 & 114 & 81.6 \\
\hline
\end{tabular}

loam had the highest cobalt content and the lowest copper content. All the soils studied had a much higher copper content than cobalt. The amount of copper was 16 times more than that of cobalt in the Toa sandy loam. In the case of the Cayagua sandy loam, the copper content was more than 400 times the amount of the cobalt present. The difference between the copper and cobalt content of the soils can be explained on the basis of the presence of more copper-containing minerals in the parent material from which the soils were derived.

According to Johnson and Graham (8) the copper and cobalt levels in the soil are a function of (a) the parent material from which the soil is derived, 
(b) the conditions prevailing during the period of soil development, (c) the amount of organic matter present in the soil, (d) soil texture, and (e) soil reaction.

The range of values for the cobalt content of the soils studied varied from

TABLE 4.-Cobalt content in grasses

\begin{tabular}{l|c|c|c|c}
\hline \multirow{2}{*}{ Grass spp. } & \multicolumn{4}{|c}{ Cobalt content } \\
\cline { 2 - 5 } & Samples & Minimum & Maximum & Average \\
\cline { 2 - 5 } & Number & $p . p . m$. & p.p.m. & $p \cdot p \cdot m$. \\
Mixture of grasses and legumes & 3 & 0.5 & 1.4 & 0.8 \\
Pasto amargo & 1 & .5 & .5 & .5 \\
Cerrillo & 1 & .4 & .4 & .4 \\
Mixture of grasses and legumes & 3 & .7 & 4.6 & 2.1 \\
Merker grass & 8 & .1 & .4 & .3 \\
Malojillo & 8 & .1 & .4 & .3 \\
\hline
\end{tabular}

1 The mixture consisted of the following: Pasto amargo, yerba dulce, carpet grass, coqui, escobilla, zarzabacoa and morivivi.

2 These are composite samples.

- Same grass-legume combination as in 1 plus San Agustin, grama de costa, arrocillo and botoncillo blanco.

TABLE 5.-Copper content in the grasses

\begin{tabular}{l|c|c|c|c}
\hline \multirow{2}{*}{ Grass spp. } & \multicolumn{4}{|c}{ Copper content } \\
\cline { 2 - 5 } & Samples & Minimum & Maximum & Average \\
\cline { 2 - 5 } & Number & p.p.m. & p.p.m. & p.p.m. \\
Mixtures of grasses and legumes 1 & 3 & 43 & 57 & 49 \\
Pasto amargos & 1 & 27 & 27 & 27 \\
Cerrillo & 1 & 33 & 33 & 33 \\
Mixture of grasses and legumes & 3 & 31 & 74 & 50 \\
Merker grass & 8 & 27 & 42 & 34 \\
Malojillo & 8 & 35 & 43 & 39 \\
\hline
\end{tabular}

1 Same grass-legume mixture in call No. 1 of table 4.

2 These are composites samples.

- Same grasg-legume mixture in call No. 4 of table 4.

a low of 0.1 p.p.m. to a high value of 5.6 p.p.m. These values are lower than values reported by Fujimoto and Sherman (4) for some Hawaiian soils. They report values ranging from 5 to 156 p.p.m. with an average of 36.1 p.p.m. of cobalt. This difference in cobalt content is mostly due to the difference in parent material. Hawaiian soils are volcanic in nature and it is possible that the presence of ferromagnesian mineral in them induces the pres- 
ence of more cobalt in those soils than there is present in the soils of Puerto Rico. Because of its ionic size and charge cobalt tends to concentrate as an impurity in ferromagnesian minerals (6).

The average cobalt content of the topmost 6 inches of soil was lower than the average cobalt content of the first 12 inches of soil. This, in part, agrees with the work of Hill et al. (6) who found that the cobalt content of New Jersey soils increased with decreasing particle size, and within each particle size-range, the cobalt content tended to increase with depth. The cobalt content of the grasses analyzed compares favorably with the ones reported in the literature. Hill et al. (6) report values ranging from 0.04 p.p.m. to 0.24 p.p.m. as the average cobalt content of crops collected in the field in New Jersey. If the cobalt values are compared with values reported in the literature $(6,17)$ it can be seen that Puerto Rican grasses are well supplied with cobalt. Table 6 compares cobalt levels of grasses of Puerto Rico with values obtained elsewhere for various grasses, legumes, and crops. White clover is the only pasture legume that has a relatively higher cobalt content than our tropical grasses in the above-ground portion of the plant.

As in the work of Fujimoto and Sherman (4) no significant relationship was found between the cobalt content of the soils and that of the grasses.

According to data gathered by Mitchell (11) unhealthy animals can be found grazing in pastures whose cobalt content varies from 0.005 to 0.17 p.p.m. Hill et al. (6) report that sheep suffer from cobalt deficiency when their feed contains less than 0.07 p.p.m. In the case of cattle, this situation develops when feed contains less than 0.04 p.p.m. The data gathered in our laboratory strongly suggest that cattle grazing in the areas where the grass samples were taken could not possibly suffer from cobalt deficiency. The author has not been able to find evidence in the literature published in Puerto Rico about symptoms in our cattle similar to the bush-sickness disease in both North and South Island in New Zealand and to the Enzootic Marasmus which occurs near the south coast of West Australia and in the southern part of South Australia. Both diseases are very similar and sheep and cattle grazing in cobalt deficient pastures exhibit the characteristic symptoms of these diseases.

The copper content (table 6 ) of the soils studied range from a minimum of 35 p.p.m. to a maximum of 144 p.p.m. The average copper content at 0-6 inches was 69.0 p.p.m. while the average at $0-12$ inches was 60.3 p.p.m. The data suggest that copper accumulates in the surface soil. This agrees in part with the data obtained by Pack et al. (12) in which he found that the copper content of A horizon was generally higher than that of $B$ horizon in New Jersey soils. Veermat and Van Der Bie (18) report an average copper content of 31 p.p.m. for soils of Java irrespective of the depth of the sample taken. The soils analyzed in Puerto Rico had an average of 
67 p.p.m. of copper irrespective of the depth of the sample taken. Thus, our soils analyzed three times as much as those from New Jersey (12) and twice as much than those of Java (18).

In order further to help interpret the data, soils were divided into two groups. In one group were placed the soils whose parent material consisted of transported alluvial deposits and the other group in which the parent

TABLE 6.-Comparison of the average cobalt content of some grasses from Puerto Rico, and values for grasses, legumes and crops obtained elsewhere and reporled in the lilerature $(6,19,13)$

\begin{tabular}{l|r|l|c}
\hline \multicolumn{1}{c|}{ Crop or plant product } & Cobalt & \multicolumn{1}{|c}{ Crop or plant product } & Cobalt \\
\cline { 2 - 4 } Red clover & $p . p . m$. & & $p . p . m$. \\
Orchard grass & 0.14 & Coffee, bean & 0.002 \\
Alfalfa & .12 & Corn, grain & .015 \\
Timothy & .10 & Lime, dried leaves & .20 \\
Ryegrass & .04 & Peas, green (edible portion) & .03 \\
Ladino clover & .05 & Rice, polished & .006 \\
Meadow fescue & .05 & Bermuda grass & .093 \\
Bird's foot-trefoil & .09 & Dallis grass & .072 \\
Bromegrass & .21 & Carpet grass & .079 \\
Blue grass & .24 & Oats (whole plants) & .070 \\
Alfalfa hay & .24 & Wheat (whole plants) & .089 \\
Beets, tops & .01 & Timothy hay & .01 \\
Clover, white (above ground & .40 & Puerto Rico Merker grass & .23 \\
portion) & 2.44 & Puerto Rico mixture of grasses & 1.43 \\
Water cress & & and legumes & \\
Lettuce, dried leaves & .15 & Puerto Rico Malojillo grass & .28 \\
Oat hay & .14 & Puerto Rico Pasto amargo & .50 \\
& .02 & Puerto Rico Cerrillo & .40 \\
\hline
\end{tabular}

material was granite and quartz-diorite as shown in the following tabulation:

\section{Transporled alltuial deposits \\ Coloso silty loam \\ Toa silt loam \\ Toa sandy loam \\ Coloso silty clay}

Gramile, quarls-diorile

Caguas clay

Cayaguá sandy loam

The average copper content of the soils derived from transported alluvial deposits was 60 p.p.m. while the average of those derived from granite and quartz-diorite was 78 p.p.m.

When the soils were grouped into two $\mathrm{pH}$ groups of acid to slightly acid and slightly acid to neutral it was found that there was no difference in copper content of the soils. The acid to slightly acid group had an average 
copper content of 66 p.p.m. and the slightly acid to neutral had an average of 68 p.p.m. of copper.

A comparison of the copper soil values from New Jersy (12), Puerto Rico and Java (18) makes it evident that the soils studied in Puerto Rico are quite well supplied with copper.

TABLE 7.-Minimum, maximum and averagc content of copper in the grass samples studied

\begin{tabular}{|c|c|c|c|c|}
\hline Grass & Minimum & Maximum & Average & $\begin{array}{c}\text { Number of } \\
\text { samples }\end{array}$ \\
\hline & p.p.m. & p.p.m. & p.p.m. & \\
\hline $\begin{array}{l}\text { Mixture of the following grasses and } \\
\text { legumes: } \\
\text { Pasto amargo } \\
\text { Yerba Dulce } \\
\text { Carpet grass } \\
\text { Coqui } \\
\text { Escobilla } \\
\text { Zarzabacoa } \\
\text { Morivivt }\end{array}$ & $\overline{43}$ & $\overline{57}$ & $\overline{49}$ & $\overline{3}$ \\
\hline Pasto Amargo & 27 & 27 & 27 & 1 \\
\hline Cerrillo & 33 & 33 & 33 & 1 \\
\hline $\begin{array}{l}\text { Mixture of the following grasses and } \\
\text { legumes: } \\
\text { San Agustin } \\
\text { Carpet grass } \\
\text { Pasto Amargo } \\
\text { Grama de Costa } \\
\text { Arrocillo } \\
\text { Zarzabacoa } \\
\text { Morivivi } \\
\text { Botoncillo blanco } \\
\text { Coqut }\end{array}$ & 31 & 74 & 50 & 3 \\
\hline Merker & 27 & 42 & 34 & 8 \\
\hline Malojillo & 35 & 43 & 39 & 8 \\
\hline
\end{tabular}

The copper content of the grasses studied varied from a minimum value of 27 p.p.m. to a maximum value of 74 p.p.m.

The average copper content of the mixture of grasses and legumes was 46 p.p.m. while that of the grasses alone was 36 p.p.m. The mixtures of grasses and legumes had also the highest content of cobalt (table 6) and copper (table 7). Bould et al. (1) report copper leaf values in the range of 1.1 to 3.0 p.p.m. for deficient apple and pear trees while values of 5.1 to 8.0 p.p.m. are designated as normal. Pack et al. (12) report average copper values of 7,11 , and 12 p.p.m. for such crops as alfalfa, red clover, and field corn 
leaves. The values found for our grasses and the grass-legume mixture are much higher than these values, thus indicating that the soils where these grasses were growing are well supplied with copper. As in the case of cobalt no significant relationship was found between the copper content of the soil and that of the grasses.

The supplying power of the soils studied for both cobalt and copper can be termed as adequate. This means that the grasses growing in them are adequately supplied with these two minerals and, in turn, the cattle grazing on them would not be expected to suffer from a deficiency of any one of these two minerals.

\section{SUMMARY}

Several soil and grass samples were collected with the purpose of determining their copper and cobalt content. One of the soils studied, Cayagua sandy loam, had the lowest cobalt content and the highest copper content. The Toa sandy loam had the highest cobalt content and the lowest copper content. In general, the soils had a much higher content of copper than of cobalt and a higher content of cobalt and copper than any of the grasses studied. The soils had about twice as much copper and cobalt as the grasses.

In all cases the mixture of grasses and legumes had a higher content of copper and cobalt than the grasses alone. The consumption of grasses by the cattle grazing in the areas where the samples were taken does not constitute a hazard for the cattle, because the grasses do not accumulate toxic amounts of the minerals.

\section{RESUMEN}

Se tomaron muestras de suelos y yerbas con el propósito de determinar su contenido de cobre y cobalto. De los suelos estudiados, el tipo de suelo Cayaguá franco-arenoso tuvo el contenido más bajo de cobalto y el más alto de cobre. El tipo de suelo Toa franco-arenoso tuvo el contenido más alto de cobalto y el más bajo de cobre. Los suelos estudiados tuvieron un contenido más alto de cobre que de cobalto. El contenido de cobre y cobalto en los suelos fue superior al de las yerbas.

La mezcla de yerbas y leguminosas fue superior en cuanto al contenido de cobre y cobalto que cualquiera de las yerbas. Las yerbas estudiadas no son un riesgo para el ganado, ya que ninguna acumula cantidades tóxicas de los minerales estudiados.

\section{LITERATURE CITED}

1. Bould, C., Nicholas, J. D., and Tolhurst, J. A. H., Copper deficiency of fruit trees in Great Britain, J. Hort. Sci. 28: 268-77, 1953.

2. Coulson, E. J., Report on Copper, J. Ass. Offic. Agr. Chem. 20: 178, 1937.

3. Drabkin, D. L., Report on Copper, J. Ass. Offic. Agr. Chem. 28: 320, 1939. 
4. Fujimoto, Guchi and Sherman, Donald E., Cobalt Content of Typical Soils and Plants of the Hawaiian Islands, Agron.J. 48: 577-81, 1950.

5. Harmer, P. M., Studies on the effect of copper sulfate applied to organic soil on the yield and quality of several crops, Soil Sci. Soc. Amer. Proc. 10: 284-94, 1945.

6. Hill, C. A., Toth, S. J., and Bear, F. E., Cobalt Status of New Jersey Soils and Forage Plants and Factors Affecting the Cobalt Content of Plants, Soil Sci. 76: 273-84, 1953.

7. Holmes, R. S., Determination of total copper, zinc, cobalt and lead in soils and soil solutions, Soil Sci. 59: 77-84, 1945.

8. Johnson, F. R., and Graham, E. R., Trace Elements and Missouri Soils, Res. Bull. 517, January 1953.

9. Marston, H. R., and Dewey, D. W., The estimation of cobalt in plant and animal tissues, Australian J. Expll. Biol. Med. Sci. 18: 343, 1940.

10. Maynard, L. A., and Loorsli, J. K., Animal Nutrition, McGraw-Hill Book Company, Inc., 533, 1962.

11. Mitchell, J. H., Cobalt Content of Pasture Plants and Feeding Materials, Bull. 391, South Carolina Agr. Expt. Sta., February 1951.

12. Pack, M. R., Toth, S. J., and Bear, F. E., Copper Status of New Jersey Soils, Soil Sci. 75: 433-41, 1953.

13. Parks, R. Q., Hood, S. L., Hurwitz, C., and Ellis, G. H., Quantitstive Chemical Micro Determination of Twelve Elements in Plant Tissue, Ind. Eng. Chem. Anal. Ed. 15 (8): 527-33, 1943.

14. Piper, C. S., Soil and Plant Analysis, Interscience Publishers, Inc., New York, 1950.

15. Roberts, R. C. and Party, Soil Survey, Puerto Rico, USDA, Bureau of Plant Industry in cooperation with the Univ. P.R., Agr. Expt. Sta., Series 1936 (8), January 1942.

16. Univ. of Fla. Agr. Expt. Sta. Annual Report, June 20, 1940.

17. Young, R. S., Cobalt: A.C.S. Monograph No. 108, Reinhold Publishing Co., N.Y. 1948.

18. Vermaat, J. G., and Van DerBie G. J., On the Occurrence of Copper in Tropical Soils, Plant and Soil \& (3): 257-82, 1950. 